\title{
PENGEMBANGAN DESAIN BLENDED LEARNING UNTUK PROGRAM PELATIHAN PENDALAMAN MATERI IPA BERBASIS KEBUTUHAN MAHASISWA PGSD
}

\author{
Suci Utami Putri \\ Sekolah Pascasarjana Universitas Pendidikan Indonesia \\ Jl. Dr. Setiabudhi No. 229 Bandung \\ Email: suci_nazwa@yahoo.com
}

\begin{abstract}
The Curriculum 2013 for primary school education which is now applied in Indonesia put emphasis on thematic learning model using the scientific approach. The application of this curriculum has raised certain concerns on teachers and student teachers of primary school. The lack of confidence and the lack of mastery of science concepts by student teachers, especially those whose major are nonscience department have the potential to affect the quality of thematic science teaching when they carry out their duties in the future. Development of in-depth understanding from science material training program and its relevance to the curriculum 2013 using blended learning model can be one of the ways to overcome these problems. Blended learning is a learning strategy that combines offline or online interaction with face-to-face learning interaction. The training programs for in-depth understanding of science material using blended learning models is expected to increase the self-confidence, mastery of science concepts, and the ability to design a thematic science learning for elementary school student teachers. Keywords: science material training program, blended learning, preservice teacher program.
\end{abstract}

ABSTRAK

Kurikulum 2013 untuk pendidikan sekolah dasar yang sekarang diterapkan di Indonesia menekankan pada model pembelajaran tematik dengan menggunakan pendekatan ilmiah. Penerapan kurikulum ini telah menimbulkan kekhawatiran tertentu pada guru dan guru siswa sekolah dasar. Kurangnya kepercayaan diri dan kurangnya penguasaan konsep ilmu pengetahuan dengan guru siswa, terutama mereka yang utama adalah nonscience departemen memiliki potensi untuk mempengaruhi kualitas pengajaran ilmu tematik ketika mereka melaksanakan tugas mereka di masa depan. Pengembangan pemahaman mendalam dari ilmu Program pelatihan material dan relevansinya dengan kurikulum 2013 dengan menggunakan model blended learning dapat menjadi salah satu cara untuk mengatasi masalah ini. Blended learning adalah strategi pembelajaran yang menggabungkan interaksi offline atau online dengan interaksi pembelajaran tatap muka. Program pelatihan untuk pemahaman mendalam tentang materi ilmu menggunakan model blended learning diharapkan dapat meningkatkan kepercayaan diri, penguasaan konsep ilmu pengetahuan, dan kemampuan untuk merancang pembelajaran sains tematik untuk SD guru siswa sekolah.

Kata kunci: program pelatihan materi sains, blended learning, program guru preservice.

PENDAHULUAN IPA atau sains merupakan salah satu bidang ilmu yang wajib dipelajari dari jenjang pendidikan dasar sampai pendidikan tinggi. Belajar melalui IPA diharapkan dapat membentuk karakter yang positif pada diri peserta didik sehingga kelak akan menjadi individu yang lebih bijaksana dalam menyikapi permasalahan-permasalahan lingkungan maupun sosial. IPA di Indonesia khususnya untuk jenjang sekolah dasar dilaksanakan terintegrasi dengan mata pelajaran lainnya dalam pembelajaran yang bersifat tematik dengan menggunakan metode saintifik.

Pendekatan tematik atau lebih sering dikenal dengan pendekatan pembelajaran terpadu yaitu suatu pembelajaran yang memadukan berbagai 
mata pelajaran di dalam suatu tema pembelajaran sehingga pengetahuan yang terbentuk pada diri peserta didik menjadi lebih komprehensif. Menurut Sa'ud,Rukmana dan Resmini (2006: 5) menyatakan bahwa pembelajaran terpadu merupakan pendekatan yang mengintegrasikan beberapa mata pelajaran yang terkait secara harmonis untuk memberikan pengalaman belajar yang bermakna kepada peserta didik. Dari pernyataan tersebut, dapat kita ketahui bahwa untuk melaksanakan pembelajaran yang bersifat tematik, maka guru perlu mengidentifikasi mata pelajaran-mata pelajaran yang memiliki keterkaitan konsep serta tujuan pembelajaran yang dapat tercapai dalam sebuah pembelajaran. Untuk mendukung hal tersebut, maka guru perlu memiliki penguasaan konsep yang memadai pada masing-masing bidang ilmu.

Implementasi pendekatan tematik di sekolah dasar memunculkan kekhawatiran-kekhawatiran tertentu khususnya terkait eksistensi mata pelajaran IPA. IPA merupakan salah satu mata pelajaran yang dianggap sulit dipahami oleh guru maupun peserta didik. Guru yang tidak memiliki kemampuan dan penguasaan konsep IPA yang baik cenderung akan mengabaikan pengintegrasian konsep IPA di dalam suatu tema. Hal ini mungkin terjadi karena guru khawatir tidak dapat menjelaskan konsep IPA dengan baik, tidak mampu melakukan percobaan IPA sederhana yang dapat mendukung pemahaman peserta didik, atau khawatir tidak mampu menjawab pertanyaanpertanyaan terkait IPA.

Kekhawatiran-kekhawatiran guru seperti yang telah diuraikan pada paragraf di atas sesungguhnya berhubungan langsung dengan kepercayaan diri atau self efficacy seorang guru dalam mengajar sains. Menurut Bandura (2008: 1), self efficacy dapat diartikan sebagai keyakinan yang dimiliki seseorang tentang kemampuannya menghasilkan serangkaian tingkah laku yang dibentuk melalui peristiwa yang terjadi berulang-ulang sehingga mempengaruhi sikap dan perilaku seorang individu dalam kehidupan sehari-hari. Jika seseorang memiliki self efficacy yang tinggi, maka ia cenderung melakukan suatu tindakan dan perilaku yang optimal sesuai dengan kemampuan yang diyakininya. Namun jika self efficacy seseorang rendah, maka ia cenderung menghindari tantangan yang ada atau ia tidak mampu memutuskan tindakan yang tepat untuk menghadapi situasi tertentu. Apabila hal ini terjadi pada diri seorang guru atau mahasiswa calon guru ketika akan mengajarkan IPA tematik, maka resiko terjadinya pembelajaran IPA tematik yang tidak bermakna akan tinggi.

Untuk mengatasi permasalahanpermasalahan yang telah diuraikan pada paragraf sebelumnya, maka LPTK sebagai lembaga pendidikan yang berperan dalam membentuk generasi guru siap guna perlu mengembangkan strategi khusus agar mahasiswa calon guru yang dibinanya memiliki kesiapan serta kemampuan yang relevan dengan tuntutan kurikulum yang berlaku saat ini. Strategi yang dapat dikembangkan untuk mengatasi hal tersebut yaitu melalui pengembangan desain program pelatihan pendalaman materi IPA berbasis blended learning bagi mahasiswa calon guru sekolah dasar.

Blended learning merupakan suatu pendekatan pembelajaran yang mengombinasikan antara pertemuan tatap muka (in-class session) dengan pembelajaran secara online sebagai upaya untuk menggabungkan keunggulan dari kedua jenis metode yang digunakan (Reay, 2001; Rooney, 2003). Selain sesi online, pembelajaran yang bersifat offline juga dapat dijadikan sebagai strategi alternatif didalam blended learning. Hal ini sesuai dengan pendapat Carman (2005) yang menyatakan bahwa salah satu komponen pembelajaran blended yaitu self-paced learningyang menegaskan bahwapembelajar dapat mengakses bahan belajar dalam bentuk text-based ataupun multimedia-bassed secara online (via web atau mobile device) maupun offline (bahan ajar cetak ataupun CD). Dari kedua pendapat tersebut, dapat kita ketahui bahwa blended learning merupakan suatu strategi pembelajaran yang mengombinasikan antara pembelajaran mandiri yang dapat dilakukan secara online maupun offline serta tatap muka. Dengan diterapkannya kombinasi antara kedua sesi tersebut, maka hasil yang diharapkan dari penerapan program dapat tercapai dengan baik.

Berdasarkan uraian di atas, maka dirasa perlu dilakukan pengembangan desain blended learninguntuk program pelatihan pendalaman materi IPA bagi mahasiswa calon guru sekolah 
dasar. Pengembangan desain ini hendaknya disesuaikan dengan kondisi dan kebutuhan mahasiswa calon guru saat ini. Oleh karena itu, terdapat beberapa pertanyaan penelitian yang akan dijawab dalam penelitian ini yaitu sebagai berikut:

1. Bagaimana pendapat mahasiswa calon guru sekolah dasar konsentrasi non-sains tentang sejauh mana mereka memerlukan pendalaman materi IPA ke-SD-an?

2. Bagaimana penguasaan konsep mahasiswa calon guru sekolah dasar konsentrasi nonsains terhadap materi IPA ke-SD-an?

3. Bagaimana self efficacy mahasiswa calon guru sekolah dasar konsentrasi non-sains untuk mengajar IPA tematik?

4. Bagaimana desain program pelatihan pendalaman materi IPA yang sesuai dengan kebutuhan mahasiswa calon guru sekolah dasar khususnya untuk konsentrasi nonsains?

\section{METODE}

Penelitian ini dilakukan dengan menggunakan metode yang bersifat kwalitatif deskriptif. Melalui penelitian yang bersifat deskriptif ini, akan diperoleh gambaran tentang kebutuhan mahasiswa calon guru sekolah dasar konsentrasi non-sains terkait kebutuhan pendalaman materi serta penguasaan konsepnya terhadap materi IPA ke-SD an. Penelitian ini dilakukan di Universitas Pendidikan Indonesia Kampus Purwakarta dengan melibatkan 63 mahasiswa calon guru yang berasal dari konsentrasi non-sains yang terdiri dari konsentrasi matematika, IPS dan bahasa. Instrumen penelitian yang digunakan untuk menjaring data tentang pendapat mahasiswa terkait tingkat kebutuhannya terhadap pendalaman materi IPA ke-SDan yaitu dengan menggunakan angket, tes tulis yang berisi soalsoal terkait seluruh materi IPA SD pada kelas tinggi untuk menjaring data penguasaan konsepnya, serta angket self efficacy untuk mengukur tingkat kepercayaan diri mahasiswa dalam mengajarkan sains tematik di sekolah dasar. Angket self efficacy ini merujuk pada STEBI (Science Teaching Efficacy Belief Instrument) menurut Enochs dan Riggs (1990). Berdasarkan hasil analisis tersebut, kemudian di rancang sebuah desain program pelatihan pendalaman materi IPA. Untuk merancang desain pengembangan program tersebut, dilakukan studi literatur yang mendalam dari berbagai sumber terkait blended learning serta kemungkinan-kemungkinan metode-metode pembelajaran lainnya yang dapat dikombinsasikan pada pengembangan program ini. Tahapan-tahapan yang dilakukan dalam penelitian ini adalah sebagai berikut:

1. Tahap analisis kebutuhan (need asessment)

Pada tahap ini dilakukan identifikasi terhadap tingkat kebutuhan mahasiswa terhadap pendalaman materi IPA ke-SDan, tingkat penguasaan konsep mahasiswa materi IPA ke-SDan dan self efficacy mahasiswa calon gurus sekolah dasar untuk mengajarkan IPA tematik di sekolah dasar.

2. Tahap analisis data dari hasil need asessment Data yang diperoleh pada tahap sebelumnya kemudian dianalisis dengan cara menghitung nilai rata-rata data angket kebutuhan mahasiswa berkenaan dengan pendalaman materi IPA ke-SDan maupun tes dengan rumus sebagai berikut:

$$
\begin{aligned}
& \qquad \bar{x}=\frac{\Sigma X}{n} \\
& \text { (Ruseffendi, 1998: 76) }
\end{aligned}
$$

Keterangan:

$$
\begin{aligned}
& \bar{x} \quad=\text { Rata-rata } \\
& \Sigma X \quad=\text { Jumlah skor dari seluruh } \\
& \text { responden } \\
& n \quad \text { = Banyaknya responden }
\end{aligned}
$$

Dari hasil analisis data, kemudian diidentifikasi materi apa saja yang dianggap perlu dipelajari kembali lebih dalam oleh mahasiswa calon guru sekolah dasar konsentrasi non-sains lalu dijadikan dasar pengembangan program yang akan dirancang. Selain kedua data tersebut, terdapat juga data self efficacy mahasiswa calon guru sekolah dasar konsentrasi nonsains untuk mengajar sains. Data dianalisis dengan menggunakan teknik analisis skala sikap.

3. Tahap studi literatur

Setelah ditentukan materi-materi IPA berdasarkan need aseement yang akan di jadikan dasar pelaksanaan program, kemudian dilakukan studi literatur terhadap berbagai referensi seperti buku-buku IPA SD, kurikulum SD tahun 2013 serta jurnal-jurnal 
yang berhubungan dengan blended learning. Dari hasil kajian literatur kemudian diperoleh pemetaan materi IPA ke-SD an yang akan dijadikan topik inti dalam program pelatihan materi IPA serta pemetaan desain pembelajaran blended yang akan dirancang untuk program pelatihan pendalaman materi IPA.

4. Tahap pengembangan desain blended learning Pada tahap ini dilakukan perancangan program pelatihan pendalaman materi IPA berbasis blended learning berdasarkan analisis kebutuhan mahasiswa calon guru sekolah dasar khususnya konsentrasi non-sains. Hasil akhir dari tahap ini adalah desain program pelatihan pendalaman materi IPA berbasis blended learning yang telah dilengkapi dengan strategi/ metode yang akan dilaksanakan pada setiap sesi pembelajaran.

\section{HASIL}

Pada bagian ini akan dijelaskan mengenai hasil analisis skor angket dan tes yang menggambarkan pendapat mahasiswa terhadap kebutuhan pendalaman materi IPA SD, penguasaan konsep, dan self efficacy yang dimiliki. Uraian tentang hasil penelitian adalah sebagai berikut:

\section{Hasil Analisis dan Pembahasan Data Angket Tentang Tingkat Kebutuhan Mahasiswa Terhadap Pendalaman Materi IPA SD}

Pada angket yang digunakan untuk mengidentifikasi tingkat kebutuhan mahasiswa calon guru konsentrasi non-sains terhadap pendalaman materi IPA terdapat pertanyaan tentang sejauh mana mahasiswa merasa perlu untuk mempelajari kembali materi IPA ke-SDan. Secara keseluruhan, terdapat enam kelompok topik IPA yang dibahas di kelas tinggi pada jenjang sekolah dasar yang terdiri dari: a) Anatomi \& Fisiologi Tubuh Manusia dan Hewan, b) Anatomi \& Fisiologi Tumbuhan, c) Makhluk Hidup dan Lingkungannya, d) Benda dan Sifatnya, d) Energi dan Perubahannya, serta e) Bumi dan Alam Semesta. Hasil analisis data angket menunjukkan bahwa dari keenam topik tersebut, terdapat tiga topik yang menurut mahasiswa masih perlu untuk dipelajari kembali. Analisis data angket tersebut dapat dilihat pada tabel berikut.
Tabel 1. Hasil Analisis Data Angket Kebutuhan Belajar Mahasiswa terhadap Materi IPA

\begin{tabular}{|c|c|c|}
\hline Topik & $\begin{array}{l}\text { Nilai } \\
\text { Rata- } \\
\text { Rata }\end{array}$ & Keterangan \\
\hline $\begin{array}{c}\text { Anatomi Fisiologi } \\
\text { Tubuh Manusia } \\
\text { dan Hewan }\end{array}$ & 3,12 & $\begin{array}{l}\text { Sangat perlu } \\
\text { dipelajari }\end{array}$ \\
\hline $\begin{array}{l}\text { Anatomi dan } \\
\text { Fisiologi } \\
\text { Tumbuhan } \\
\end{array}$ & 3,09 & $\begin{array}{c}\text { Sangat Perlu } \\
\text { dipelajari }\end{array}$ \\
\hline $\begin{array}{l}\text { Makhluk Hidup } \\
\text { dan } \\
\text { Lingkungannya }\end{array}$ & 2,41 & Perlu dipelajari \\
\hline $\begin{array}{c}\text { Benda dan } \\
\text { Sifatnya }\end{array}$ & 2,1 & Perlu dipelajari \\
\hline $\begin{array}{c}\text { Energi dan } \\
\text { Perubahannya }\end{array}$ & 2,87 & Perlu dipelajari \\
\hline $\begin{array}{c}\text { Bumi dan Alam } \\
\text { Semesta }\end{array}$ & 3,27 & $\begin{array}{c}\text { Sangat perlu } \\
\text { dipelajari }\end{array}$ \\
\hline
\end{tabular}

Dari tabel tersebut dapat kita lihat bahwa terdapat tiga topik IPA yang berada pada kategori sangat perlu dipelajari kembali oleh mahasiswa calon guru sekolah dasar konsentrasi non-sains karena memiliki nilai rata-rata lebih dari 3 yang terdiri dari topik Anatomi dan Fisologi Tubuh Manusia dan Hewan, Anatomi Fisiologi Tumbuhan, serta Bumi dan Alam semesta. Tiga topik lainnya berada dalam kategori perlu dipelajari, tapi jika kita perhatikan kembali nilai rata-rata pada tiga topik tersebut berada pada area yang tidak mendekati angka 3 kecuali pada topik energi dan perubahannya yang memiliki nilai rata-rata mendekati 3. Untuk meyakinkan hasil analisis angket ini, maka dilakukanlah tes penguasaan konsep mahasiswa calon guru sekolah dasar konsentrasi non-sains. Tes berisi sejumlah soal yang berhubungan dengan kelima topik IPA ke-SDan.

\section{Analisis Data Tes Penguasaan Konsep Mahasiswa terhadap topik IPA ke-SD-an}

Tes penguasaan konsep dilakukan untuk memberikan gambaran sesungguhnya tentang sejauh mana kemampuan mahasiswa dalam menjawab soal-soal yang berhubungan dengan topik IPA SD. Hal ini bertujuan untuk memberikan data pembanding terhadap data angket yang dapat dijadikan bahan pertimbangan untuk memutuskan topik apa saja 
yang sangat urgen untuk dipelajari kembali oleh mahasiswa calon guru sekolah dasar konsentrasi non sain. Hasil analisis data tes dapat dilihat pada tabel berikut.

Tabel 2. Hasil Analisis Tes Penguasaan Konsep Mahasiswa terkait Topik IPA

\begin{tabular}{|c|c|}
\hline Topik & $\begin{array}{c}\text { Persentase } \\
\text { Mahasiswa } \\
\text { Menjawab Benar }\end{array}$ \\
\hline $\begin{array}{c}\text { Anatomi Fisiologi Tubuh } \\
\text { Manusia dan Hewan }\end{array}$ & $41,85 \%$ \\
\hline $\begin{array}{c}\text { Anatomi dan Fisiologi } \\
\text { Tumbuhan }\end{array}$ & $26,46 \%$ \\
\hline $\begin{array}{c}\text { Makhluk Hidup dan } \\
\text { Lingkungannya }\end{array}$ & $61,55 \%$ \\
\hline Benda dan Sifatnya & $76,19 \%$ \\
\hline Energi dan Perubahannya & $66,89 \%$ \\
\hline Bumi dan Alam Semesta & $47,8 \%$ \\
\hline
\end{tabular}

Dari tabel tersebut, dapat kita lihat bahwa terdapat tiga topik IPA yang memiliki persentase di bawah 50\% yang terdiri dari topik Anatomi
Fisiologi Tubuh Manusia dan Hewan, Anatomi dan Fisiologi Tumbuhan serta Bumi dan Alam Semesta. Hal ini menunjukkan bahwa sebagian besar mahasiswa tidak dapat menjawab soal-soal tersebut dengan benar. Sementara itu, tiga topik lainnya memiliki nilai persentase di atas 50\% yang menunjukkan bahwa sebagian besar mahasiswa calon guru konsentrasi non-sains dapat menjawab soal-soal terkait topik tersebut dengan benar.

Analisis Data Angket Self efficacy Mahasiswa Calon Guru Sekolah Dasar Untuk Mengajar IPA Tematik

Self efficacy yang diukur dalam penelitian ini terdiri dari dua indikator yaitu Personal Science Teaching Efficacy (PSTE) dan Science Teaching Outcome Expectancy (STOE) merujuk pada STEBI yang dirancang oleh Enoch dan Riggs (1990) yang dimodikasi sesuai dengan kebutuhan penelitian. Hasil analisis data angket tersebut dapat dilihat pada diagram berikut.

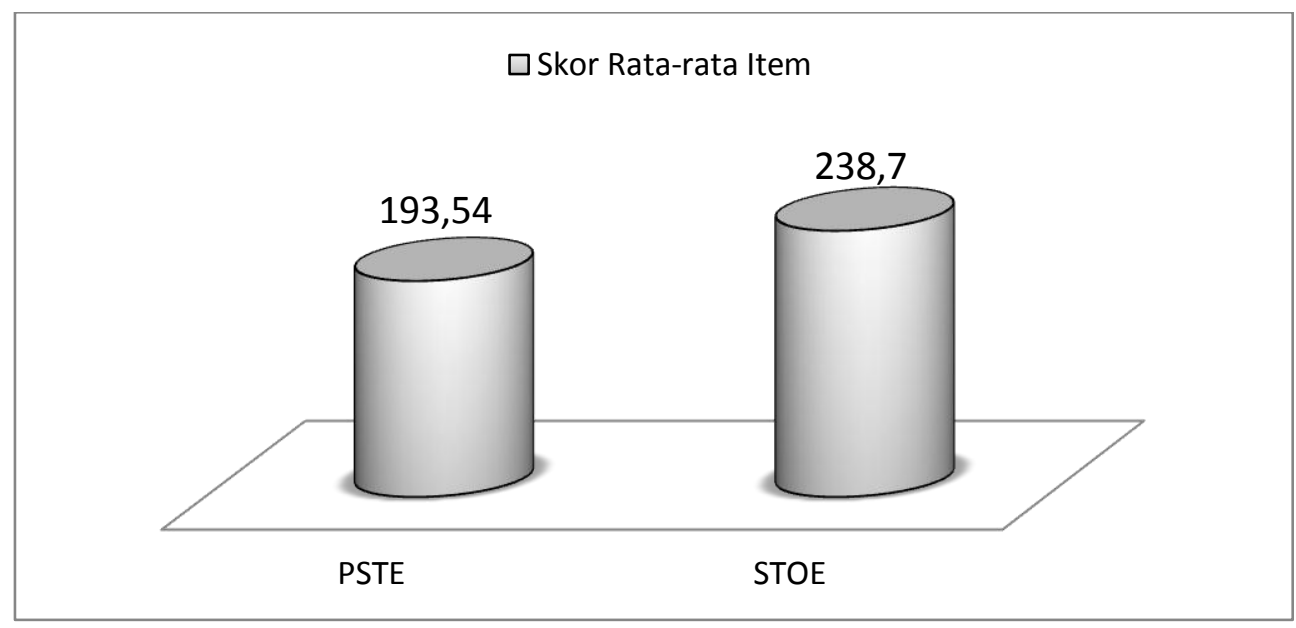

Gambar 1. Diagram Hasil Skor Rata-rata Self efficacy Mahasiswa Calon Guru SD Konsentrasi Nonsains

Berdasarkan hasil analisis angket self efficacy mahasiswa calon guru sekolah dasar konsentrasi non-sains diperoleh data bahwa skor rata-rata indikator PSTE adalah 190,2 termasuk kedalam kategori "Ragu-ragu" sedangkan STOE adalah 238,7 berada pada kategori "Yakin/Setuju" terhadap item pernyataan yang disajikan. PSTE yang masuk kedalam kriteria "ragu-ragu" menunjukkan mahasiswa calon guru sekolah dasar konsentrasi nonsains belum punya cukup keyakinan terhadap kemampuan yang dimilikinya terkait pembelajaran IPA tematik yang akan dilaksanakan di sekolah dasar.

\section{PEMBAHASAN}

Dari hasil analisis data angket kebutuhan mahasiswa terhadap pendalaman materi IPA dan tes di atas, dapat kita lihat bahwa keenam topik IPA berada pada kategori sangat perlu dipelajari dan perlu dipelajari kembali. Hasil angket ini kemudian dikroscek dengan data hasil tes penguasaan konsep mahasiswa terhadap 
keenam topik IPA tersebut. Rekapitulasi kedua data tersebut dapat dilihat pada tabel berikut.

Tabel 3. Rekapitulasi Data Angket Kebutuhan Mahasiswa terhadap Pendalaman Materi IPA dan Tes Penguasaan Konsep

\begin{tabular}{|c|c|c|c|}
\hline Topik & $\begin{array}{c}\text { Nilai } \\
\text { Rata- } \\
\text { Rata }\end{array}$ & $\begin{array}{c}\text { Persentase } \\
\text { Jawaban } \\
\text { Benar }\end{array}$ & $\begin{array}{c}\text { Keterang } \\
\text { an }\end{array}$ \\
\hline $\begin{array}{c}\text { Anatomi } \\
\text { Fisiologi Tubuh } \\
\text { Manusia\& } \\
\text { Hewan }\end{array}$ & 3,12 & $41,85 \%$ & Urgen \\
\hline $\begin{array}{c}\text { Anatomi dan } \\
\text { Fisiologi } \\
\text { Tumbuhan }\end{array}$ & 3,09 & $26,46 \%$ & Urgen \\
\hline $\begin{array}{c}\text { Makhluk Hidup } \\
\text { dan } \\
\text { Lingkungannya }\end{array}$ & 2,41 & $61,55 \%$ & Tidak \\
\hline $\begin{array}{c}\text { Benda dan } \\
\text { Sifatnya }\end{array}$ & 2,1 & $76,19 \%$ & Tidak \\
\hline $\begin{array}{c}\text { Energi dan } \\
\text { Perubahannya }\end{array}$ & 2,87 & $66,89 \%$ & Tidak \\
\hline $\begin{array}{c}\text { Bumi dan Alam } \\
\text { Semesta }\end{array}$ & 3,27 & $47,8 \%$ & Urgen \\
\hline
\end{tabular}

Dari tabel di atas, dapat kita lihat bahwa topik Anatomi Fisiologi Tubuh Manusia dan Hewan memiliki nilai rata-rata angket 3,12 yang masuk kedalam kategori sangat perlu dipelajari. Data tes penguasaan konsep pada topik tersebut menunjukkan hanya 41, 85\% mahasiswa yang mampu menjawab benar. Oleh karena itu, topik ini diputuskan sebagai topik yang sangat urgen untuk dipelajari kembali oleh mahasiswa. Kondisi yang sama juga terjadi pada topik Anatomi Fisiologi Tumbuhan dengan Bumi dan Alam Semesta. Antara nilai rata-rata dengan persentase mahasiswa yang menjawab benar pada kedua topik tersebut berbanding lurus. Berdasarkan hasil angket kedua topik tersebut memiliki nilai rata-rata yang masuk kedalam kategori sangat perlu dipelajari dengan persentase mahasiswa yang menjawab benar soal tes pada topik tersebut di bawah $50 \%$. Sehingga kedua topik ini juga diputuskan sebagai topik yang urgen untuk dipelajari kembali oleh mahasiswa calon guru konsentrasi non-sains. Untuk topik Makhluk Hidup dan Lingkungan serta Benda dan Sifatnya, diputuskan sebagai topik yang tidak terlalu urgen untuk pelajari kembali oleh mahasiswa karena nilai rata-rata yang rendah di bawah 2,5 bahkan hampir mendekati 2 menunjukkan sesungguhnya banyak mahasiswa yang menyatakan bahwa topik ini tidak terlalu perlu untuk dipelajari kembali. Selain itu, data tes penguasaan konsep terhadap kedua topik tersebut menunjukkan nilai persentase yang besar di atas 50\%. Hal ini menunjukkan bahwa sebagian besar mahasiswa telah mampu menjawab soal-soal terkait kedua topik tersebut dengan benar. Untuk topik Energi dan perubahannya, hasil angket mahasiswa menunjukkan bahwa nilai rata-ratanya yang masuk kedalam kategori perlu dipelajari. Namun jika diperhatikan, nilai rata-rata pada topik ini hampir mendekati 3. Dengan kata lain, banyak mahasiswa yang mengganggap bahwa topik ini sangat perlu untuk dipelajari kembali. Ketika data angket dibandingkan dengan data tes penguasaan konsep, diketahui persentase mahasiswa yang menjawab benar soal-soal yang terkait topik tersebut berada pada nilai di atas $50 \%$. Hal ini berarti tidak banyak mahasiswa yang kesulitan menjawab soal terkait topik ini. Berdasarkan hal tersebut, maka topik ini diputuskan sebagai topik yang tidak terlalu urgen untuk dipelajari kembali.

Terkait hasil analisis angket self efficacy, diketahui bahwa PSTE mahasiswa masuk ke dalam kategori "ragu-ragu". Sementara itu, STOE mahasiswa masuk ke dalam kategori "Yakin". Hal ini menunjukkan bahwa sesungguhnya mahasiswa calon guru sekolah dasar meyakini bahwa guru memiliki peran penting dalam meningkatkan prestasi sbelajar sains peserta didik, namun mereka belum cukup yakin bahwa mereka mampu melaksanakan pembelajaran IPA tematik dengan baik di sekolah dasar. Berdasarkan hal tersebut maka diperlukan suatu rancangan program pelatihan yang dapat membantu mahasiswa dalam meningkatkan penguasaan konsepnya terkait IPA sekaligus meningkatkan kepercayaan dirinya (self efficacy) dalam mengajar IPA tematik.

Berdasarkan uraian di atas, ketiga topik IPA yang telah ditentukan serta hasil analisis angket self efficacy mahasiswa dijadikan titik tolak untuk mengembangkan suatu program pelatihan yang dapat membantu mahasiswa konsentrasi nonsains untuk meningkatkan penguasaan konsep dan self efficacynya dalam mengajar IPA tematik di sekolah dasar. Berdasarkan hasil 
kajian literatur dari berbagai sumber, blended learning dapat dijadikan suatu pilihan yang strategis untuk mengatasi permasalahan yang terjadi. Blended learning merupakan kombinasi antara sesi belajar mandiri dengan sesi tatap muka. Reay (2001) dan Rooney (2003) menyatakan bahwa Blended learning merupakan suatu pendekatan pembelajaran yang mengombinasikan antara pertemuan tatap muka (in-class session) dengan pembelajaran secara online maupun offlinesebagai upaya untuk menggabungkan keunggulan dari kedua jenis metode yang digunakan.

Rancangan program pelatihan blended learning yang akan dikembangkan yaitu mengombinasikan antara sesi belajar offline dengan bantuan multimedia interaktif, sesi online via edmodo, dan tatap muka. Multimedia interaktif yang digunakan akan dikembangkan sesuai dengan tiga topik IPA yang telah ditentukan berdasarkan hasil analisis angket kebutuhan pendalaman materi IPA dan hasil tes penguasaan konsep yang terdiri dari Anatomi Fisiologi Tubuh Manusia dan Hewan, Anatomi Fisiologi Tumbuhan serta Bumi dan Alam Semesta. Berhubung topik tentang Anatomi dan Fisiologi Tubuh Manusia dan Hewan terlalu banyak, maka topik ini dibagi menjadi dua yang terdiri dari: a) Sistem Organ Tubuh Manusia dan Hewan, dan b) Alat Indera serta Hubungannya dengan Konsep Cahaya dan Bunyi. Setiap sesi kegiatan dalam program ini memiliki kegiatan yang berbeda. Pemetaan kegiatan antara sesi offline, online dan tatap muka dapat dilihat pada bagan berikut.

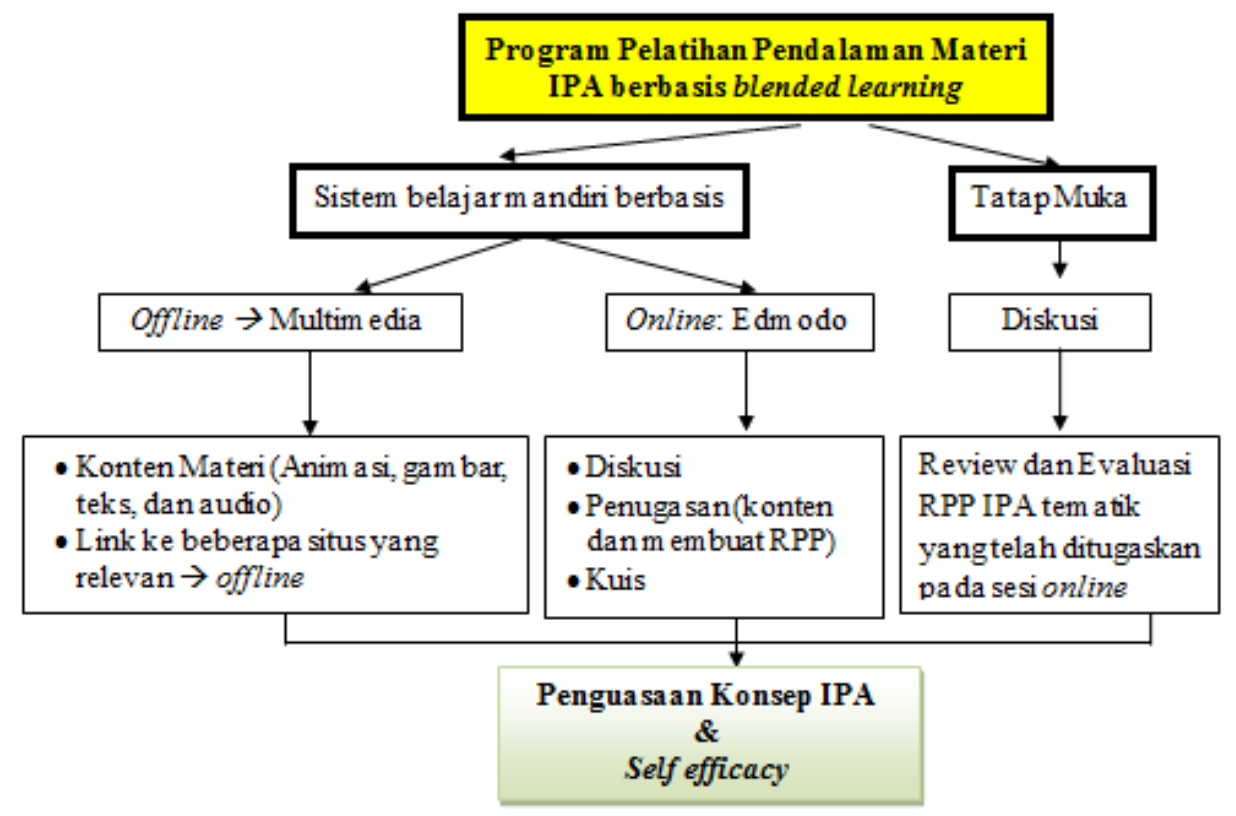

Gambar 2. Bagan Rancangan Pengembangan Program Pelatihan Pendalaman Materi IPA bagi Mahasiswa Konsentrasi Nonsains

Dari Bagan di atas, nampak jelas rancangan pengembangan program pelatihan pendalaman materi IPA berbasis blended learning ini fokus pada aspek kegiatan pembelajaran yang memungkinkan mahasiswa kosentrasi nonsains memiliki kesempatan untuk mempelajari topik IPA lebih dalam melalui sesi offline dan online kemudian mencoba mengimplementasikan pengetahuan yang dimilikinya kedalam bentuk RPP IPA tematik untuk sekolah dasar. Setiap kegiatan pelatihan saling berkesinambungan satusama lain sehingga pengetahuan yang akan dicapai mahasiswa calon guru sekolah dasar khususnya konsentrasi non-sains akan lebih komprehensif karena meliputi penguasaan terhadap konten ke-IPAan, self efficacy serta kemampuan merancang pembelajaran IPA tematik.

\section{SIMPULAN}

Berdasarkan uraian di atas, dapat disimpulkan bahwa mahasiswa calon guru 
sekolah dasar konsentrasi non-sains bependapat bahwa tiga topik IPA SD yang terdiri dari Anatomi, Fisiologi Tubuh Manusia dan Hewan, Anatomi Fisiologi Tumbuhan serta Bumi dan Alam Semesta masih sangat perlu dipelajari. Hal ini didukung oleh hasil tes penguasaan konsep yang menunjukkan bahwa sebagian besar mahasiswa (> 50\%) tidak dapat menjawab pertanyaan terkait ketiga topik tersebut. Selain itu, hasil analisis angket self efficacy menunjukkan bahwa Personal Science Teaching Efficacy (PSTE) mahasiswa masuk ke dalam kategori "raguragu". Hal ini menunjukkan bahwa mahasiswa calon guru sekolah dasar konsentrasi nonsains masih meragukan kemampuan yang dimilikinya untuk mengajar IPA tematik. Berdasarkan hal tersebut maka dirancang suatu program pelatihan pendalaman materi IPA dengan mengembangkan modelblended learning yang mengombinasikan antara sesi offline (belajar topik IPA melalui multimedia), online (diskusi, penugasan, dan kuis via edmodo), dan tatap muka (evaluasi RPP IPA tematik). Melalui program pelatihan yang dirancang seperti ini diharapkan dapat dijadikan alternatif kegiatan yang diselenggarakan oleh LPTK untuk mendukung terwujudnya generasi guru yang profesional.

\section{REFERENSI}

Bandura, A. (2008). Self efficacy. Tersedia Online di: $\quad$ http://www.des.emory.edu/mfp/ BanEncy.html.

Carman, M.J. (2005). Blended learning Desain: Five Key Ingredients. Online di: http://www.agilantlearning.com/pdf/Blended \%20Learning\%20Design.pdf.

Enochs, L., \& Riggs, I. (1990). Further Development of an Elementary Science Teaching Efficacy Belief Instrument. School Science and Mathematics, 10, 194-202.

Reay, J. (2001). Blended learning a Fusion for the Future. Knowledge Management Review, 4(3): 6.

Rooney, J. E. (2003). Blended learning Opportunities to Enhance Educational Programming and Meetings.Association Management, 55(5), 26-32.

Ruseffendi, E.T. (1998). Statistika Dasar. Bandung: IKIP Bandung Press

Sa'ud, S.U., Rukmana, A., dan Resmini, N. (2006). Pembelajaran Terpadu. Bandung: UPI Press. 